\title{
Traditional Folk Media for Environmental Communication and Preservation in Guna Community, Amhara, Ethiopia
}

\author{
Destaw Bayable Yemer \\ Guna Tana Integrated Field Research \& Development Center, Debre Tabor University, Ethiopia \\ Email:kiyafeama@gmail.com
}

\begin{abstract}
This study focused on the assessment of folk media aimed at Environmental Communication (EC) in the Guna Community and suggested the dominant Guna Community folk media for environmental communication and preservation to conserve Mount Guna. Guna Mount is the home of different biodiversity and the tower of water, but it is becoming degraded. Folk media are operative in environmental communication and preservation. They have the power to transmitted environmental messages that incorporate cultural values, beliefs, and attitudes with societal needs. Folk media are locally oriented, easily accessible, flexible, portable, inclusive, and relatively inexpensive. A qualitative research approach was employed for this research. Ethnographic research design, snowball, and purposive sampling techniques were used to select the respondents. The researchers were gathered the data through in-depth interviews, focus group discussion, and observation. For this survey, 16 FGDs, 45 individual in-depth interviews, and participant observation were employed. Guna community has unique and indigenous folk media that use as a source of entertainment, information, and education. Their folk music, songs, dances, campfire storytelling, traditional motifs, fairs, and festivals, and folk poems are the dominants. Using folk media for operative ecology preservation is vital in the form of EC that inspires and develops positive behavior in the community by educating about environmentalism in the method of facilitating environmental issues incorporating the latest message. Finally, we recommended some folk media for developmental activities that use inform of advocacy regarding recommended reasons
\end{abstract}

Key Words: Environmental Communication, Environmental preservation, Folk media, Guna community

\section{Introduction}

Folk media should be an integral part of any communication program for rural development. It is a dynamic means of communication. It can integrate cultural values, beliefs, and attitudes with national and societal needs. Understanding of the rural audience is prerequisites to the use of folk media that attract the mass attention and ensure their participation in developmental activities (Indian People's Theater Association, 1943). Folk media is the unique in nature, as it looks like the day-to-day life pattern of the rural masses. This type of media is a source of communal entertainment for the audience of rural areas, in addition to providing education and information to the people.

Folk media play crucial roles in environmental communication as a medium of communication. Environmental communication is the sharing of information, insights, and opinions on 
environmental issues, trends, conditions, and solutions using any means of communication, ranging from interpersonal methods to means of mass communication using the modern as well as traditional media (Bhagwati, 2016). It is a communication that focuses on the application of communication approaches, principles, strategies, and techniques to environmental protection and management (Flor, 2004). It refers to the study and practices of how individuals, societies, and the culture craft, distribute, receive, understand, and use messages about the environment and human interactions. It is also connected with environment education, public participation, and environmental politics. It is the communication of ecological data and information between various audiences using different media.

In line with the above, folk media have their significance to change the attitudes of the society in the form of communication. Environmental communication focuses on the ways people communicate about the natural world and conservation affairs. It examines the public's perceptions of the real world and how these perceptions shape human-nature relations (Jarreau, Altinay, \& Reynolds, 2015).

Environmental human communication is constitutive because it helps to shape people's understandings of environmental issues, themselves, and nature; it shapes the meanings we hold of these things. Our societies are face challenges and many environmental problems, like deforestation, biodiversity loss, climate change, pollution, acidification of the oceans, and depletion of the ozone layer. Guna Mountain Community Based Conservation area needs high movement to protect natural resources in the area. It is the area that the environmental scholars and activists do sturdily for effective natural resources management, and generates, mass consciences for the protection or habitation of dying resources. The mountain is a degraded area inform of grazing and harvesting.

The interactions of the Guna community with the environment are high, but they don't protect the ecology; however, environmental communication enhances environmental literacy and sustainable environment practices (Manfred, 2000). Folk media have their contribution to maintaining the community environmental literacy. Beside to these social norms and influences the community practices in the preserved area. Social norms consist of beliefs or perceptions about common or accepted behaviors within a group (Cialdini \& Trost, 1998). Environmental Communication (EC) is usually connects with environmental education, public participation, and environmental politics. It is the foundation establishing relationships between people and the environments. It also enhances environmental literacy and sustainable environmental practices (Manfred, 2000).

In a different context, EC is closely connects with sustainable development (SD), which can only be successful if it is based on sufficient, reliable and comparable information, indicators, free access to information and unhindered information flows www.sustainableliving.org/appen-a.htm. Environmental communicators have recognized the value and power of using folklore and traditional media for communication. Folk media which is usually used at the small cluster or local level to communicate with the society like folk choral, drum beating, native riddles, folk dancing, wall chalking, the poetry of local saints and the local theaters which originate under the realm of folk media. Folk media is also known as the fundamental media or community media. It is the face-to-face communication procedure, and it is very operative as the audiences have straight communication with the medium or the communicator. 
The folk media satisfy the innate community need for self-expression for moral instruction combined with entertainment. It helps to express the community's internal feelings and represents the social identity. Besides this, they can preserve and disseminate the messages in lively manners, and transfer the value and culture of our forefathers. The urge to express, communicate, and share something beautiful gave birth to performing arts such as folk and traditional media. In the Ethiopian context, the media have numerous contributions to development activities. Folk media has much significance; it used for the moral, religious and socio-political purpose, it is personal, familiar credible forms, their targeted people are literate and illiterates, it discusses the contemporary issues on its themes, and folk forms are religion, community, caste, culture and language/dialect-specific and bear values (Juvvigunta, 2017).

As I mentioned above, folk media plays a dynamic role for environmental communication and preservation. Folk media is the representatives of the real-life of the society. It is the means to provide information and education in forms of entertainment. Developing countries have a rich inheritance of folk art, folk tales, folk dance, classics, ballads, and dramas that can be use for the development work in the society. These media have powers to address messages for both literate and illiterate society that have an intense heritage of culture. Folk media can overcome the effort of language, dialogue, words, and other communication barriers like understanding, clarification, curiosity, attitude, and perception. Folk media have an extraordinary impression on the rural society, because of their adequate idioms, purposeful significance, and entertainment component.

Folk media can integrate environment into development policy, and to use communication and education is an integrated way as an instrument of policy. Folk songs have played important role in the patriotism movements in our country. "Public participation improves the quality, and legitimacy of the decision and ... can lead to better results in terms of environmental quality" (Paul Stern \& Dietz, 2008). Environmental collaboration and conflict resolution is the best method to conserve the Guna Gua'sa and sustain the area.

According to Ethiopian Central Statistical Office (CSA) 2010 report, more than 114,931 peoples have dwelt in the surrounding kebeles of Guna, of which $21.2 \%, 37.6 \%$ and $42.2 \%$ are from Misrak Estie, Farta, and Lay Gaint woredas, respectively and when it projected there are about $1,838,896$ people currently live in Guna surrounding kebeles. The highlander's inhabitant livelihood is mainly characterized by subsistence agriculture, which includes crop farming and animal husbandry. So, ecosystem elements of mount Guna are critically important for the local community subsistence; provide fodder, water, construction material, firewood, etc.

Historically, folk media have played a role in informing, instructing, and motivating specific audiences. Folk media are flexible, portable, and generally inexpensive. There are valuable contributions to be made by folk media to support and promote development in developing countries. Folk media can integrate cultural values, beliefs, and attitudes with national and societal needs. Indigenous media are locally oriented, easily accessible, and relatively inexpensive. Folk media include visual, verbal, and aural forms accepted by a specific community and used to entertain, inform, or instruct (Valbuena, 1988).

As most scholars argued, "Environmentalism began with environmental communication" (Flor, 2004). EC is the application of communication approaches, principles, strategies, and techniques to environmental management, and protection. It means, it is the exchange of environmental information, knowledge, and wisdom. It is a two-way social interaction process enabling the 
people concerned to understand key environmental factors and their interdependencies and to respond to problems in a competent way (OECD, 1999). It allows for greater participation of the public. It enables and empowers the audience an active participants in environmental communication.

Environmental communication focuses on the ways people communicate about the natural world and environmental affairs. It gives emphasis to the public's perceptions of the real world and how these perceptions shape human-nature relations. Environmental communication is "the strategic use of communication processes and media products to support effective policymaking, public participation, and project implementation geared towards environmental sustainability" (WPDCE, 1999).

Environmental Communication is the planned and strategic use of communication processes and media products to support effective policy makers, public participation, and project implementation geared towards environmental sustainability. It should be specific and aimed at increasing knowledge, influencing attitudes, and changing practices of intended beneficiaries about a particular action (OECD, 1999). Environmental, social, and conservation psychology researches identified many factors that can affect such behavior, including knowledge, attitudes, values, emotions, individual perceptions of efficacy and responsibility, social norms, feedback, prompts, reinforcements, goals, and behavioral affordances (Knoot, 2011). 90\% of the world's population lives in developing countries, and $70 \%$ of them live in rural areas. Mass media such as newspapers, television, and the internet don't effectively reach these people, or as many research studies show, these media do not have the required impact in terms of motivating change, and development.

Here, the Guna community, there are many vital and indigenous folk media that uses in their day-to-day activities. The community expresses their feelings in forms of folk media. These media also have an attachment to their environment, religion, culture, norm, living standard, and language. It has acceptability in the community in different forms. In Guna, most of the society lead their lives depend on agriculture. However, the ecosystem becomes degraded and demolished due to grazing and plow. Due to these, assessing the folk media that community use is essential to assign them for environmental communication for environmental protection and habitation.

\section{Basic Research Questions}

- RQ1: What types of folk media use the Guna community?

- RQ2: What are the most vital functions of folk media for environmental communication currently practiced the Guna Community?

- RQ3: How can environmental communications integrate with folk media to protect the area?

- RQ4: How do environmental communications an alternative means of protection/ habitation the ecology?

Based on the research questions stated above, the researchers forward the following hypothesis. 
H1: Guna community will have diverse types of folk media which they use for different purposes. These will be "fukera", "kererto", "shilela", "enigurguro", "fuchet", "children play”, wedding ceremony", "mahiber", "women songs and plays" etc.

- H2: Folk media will play a prominent role in the success of the Guna Mountain Conservation area. In the success of the Guna Mountain Conservation area, mouth publicity in the local dialect, religious sentiments, and personalized approach of the Guna Guassa will play positive role to in generating massive participation in this campaign. Mostly people attended religious congregation, ceremonials' of festivities (i.e., Wedding, morn, "mahiber", Christianity and "tertim"), and believes related to the Guna Mountain Conservation area.

$>$ H3: Environmental communication will integrate with folk media to protect Guna Mount in the form of strategic use of communication processes and media products to support effective policy-making, public participation, and project implementation geared towards environmental sustainability. Folk media can integrate cultural values, beliefs, and attitudes with national and societal needs.

> H4: The society is dependent on Guassa in different forms. To habitat the ecology, environmental communication will be one means of mechanism.

\section{Objectives of the Study}

The general objective of the study was to assess the folk media, which uses for environmental communication and preservation in Guna Community.

The specific objectives of the study were the followings;

1. To investigate the types of traditional folk media that focus on environmental communication,

2. To interpreting the implications of the folk media usage for operative ecology preservation,

3. To select and assign the folk media for developmental activities, which use for advocacy

\section{Research Methodology}

\subsection{Research Design}

Methodologically, this study employed an ethnographic research design, which is a "description based on intimate, long-term reflexive encounters between scholars and the peoples they are studying" (Haradhan, 2018). It is a systematic study of a particular cultural group or phenomenon, based upon extensive fieldwork in one or more selected locales. Ethnography is a written description of specific culture; the customs, beliefs, and behavior-based on information collected through fieldwork (Johnson \& Harris, 2000). Thus, the appropriateness of the ethnography method to this study is useful to critically analyze interconnected socio-cultural issues in a given social context (Sarantakos, 2013).

\subsection{Data collection methods}

As most scholars argued, ethnography researcher employed observation, interviews, and scrutinize relevant archives and artifacts are main, but still the specific method used by ethnographers depends on the overall objective of the study and the definite study setting 
(Obijiofor, 2015). For that reason, this study investigate the commonly used folk media forms and types, which focus on environmental communication, are the objectives, to do this, participant observation, Focus group discussion, and document review.

Thus, this diversity of research methods also allows the researchers to triangulate, or crosscheck, the accuracy of collected data and analytic statements. This blend techniques of data gathering are becoming highly valuable to obtain a full understanding of folk media types and forms and their potential for environmental communication in the Guna community.

\subsubsection{Focus Group Discussions}

It is relevant to find out detailed information to a particular group of people when little information is mainly known about them (Bryman, 2004). Folk media forms are mostly unwritten and orally transmitted to one generation to the next generation that made them little recognized.

Thus, using FGDs helps to examine how individuals "collectively make sense of a phenomenon and construct meanings around it" (Bryman, 2004). It helps discussants to "provide checks and balance" on each other that weed out false or extreme views (Flick, 2002) FGDs are also costeffective, provide rich data and insights (produced by group interaction), which would be less accessible without interactions (Kruger \& Casey, 2009).

\subsubsection{In-depth interviews}

"Ethnographers use interviews to help classify, and categorize an individual's perception of reality" (Fetterman, 2010). However, ethnographic interviews are less formal and less interviewdriven than the traditional interview formats.

In this study, the main reason to use in-depth interviews is to obtain detailed individual experiences and thoughts from different participants about folk media forms and their potential for environmental communication in the Guna community. Though interviews were conduct with rural households in all districts (Farta, Estie, Lay Gayint, and Guna Begimedir) in their villages, on work places, and venues for public meetings.

\subsubsection{Participant observation}

In this study, the researchers used participant observation; the researcher wanted to share the life and activities of the people in the real setting. It helps us to know and understand the potentials of folk media aimed at environmental communication. Participant observation denotes fieldbased observation that including participant observation, fieldwork, qualitative observation, direct observation, and field research (Gobo, 2008); (Patton, 2002).

The reason to focus on involvement is that participant observation helps the researchers to raises all of their senses on all sources of natural environments of the community. Ethnographers themselves experience events in the same way as the local people (Gobo, 2008); (Murchison, 2010).

\subsubsection{Document reviews}

The review of documents is an unobtrusive method. It is a content analysis; the systematic examination of forms of communication to document patterns objectively. In this study, 
documents are accessed from government offices and individuals. They are selected purposively based on their contents and relevance to the overall objective of the study.

\subsection{Site selection and sampling procedures}

\subsubsection{Site selection}

This site was selected based on the catchment areas of the Guna Tana Integrated Field Research and Development Center. The center develops a mega project to preserve the watershed which focused on alliterative livelihood options. Though, this research would have a contribution to this project.

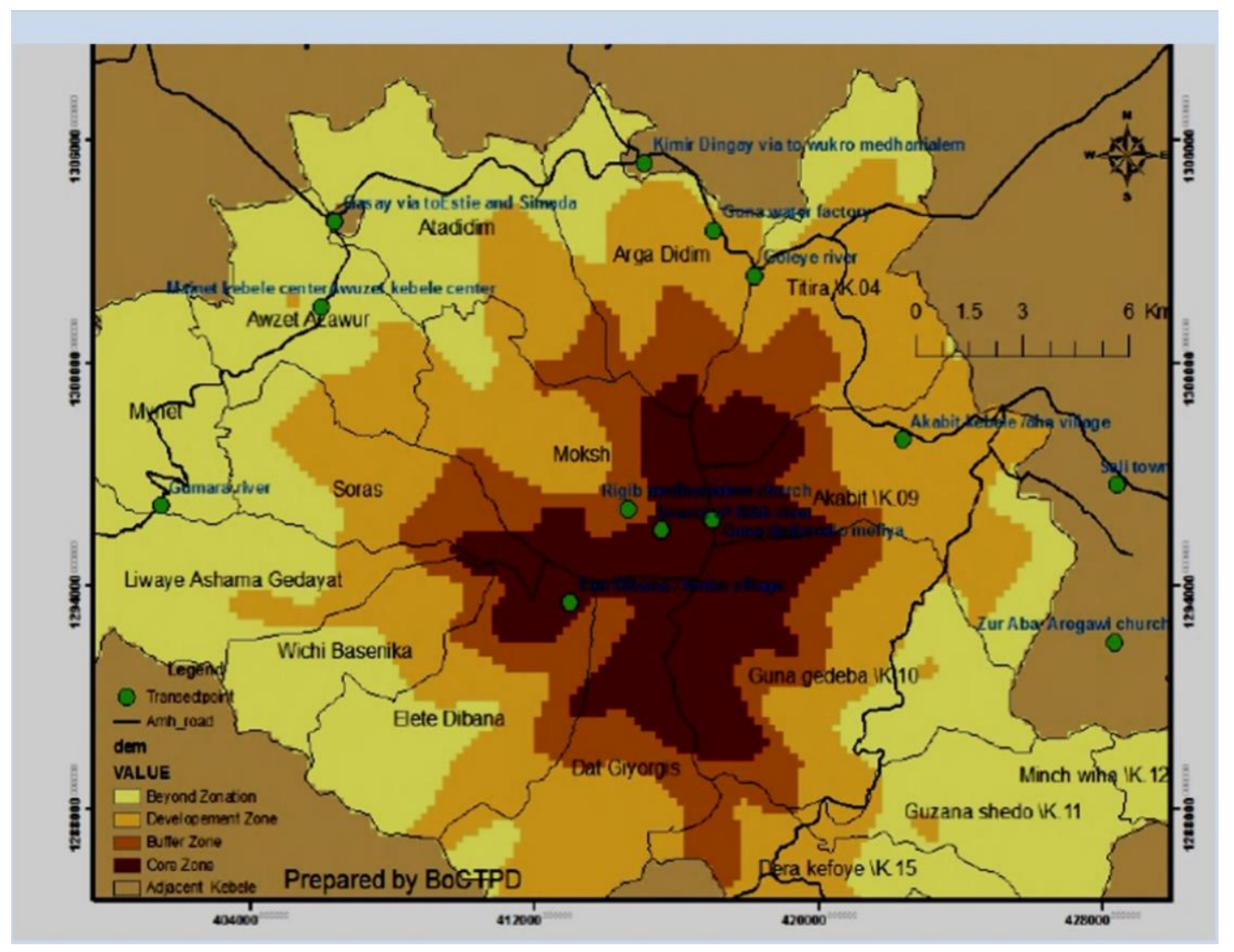

Source: Guna-Tana Integrated Field Research and Development Center-2017

\subsubsection{Sampling procedure}

The ethnographic study is guided by purposive sampling techniques relying on relatively small samples or even a single case sometimes, which provides every detail a convinced study aspires to address. Thus, samples are chosen for a purpose, to access people, times, and settings that are representative of a given criterion (Ritchie \& Lewis, 2003). As (Morse, 2006) stated, the main emphasis for ethnographic samples is on meaning rather than on the frequency of events. In this study, research participants in the Guna Community are select purposefully based on their age, gender, and their active involvement in environmental communication (household focused).

Besides purposive sampling, networking sampling techniques was employ for selected data gathering methods. Snowball sampling or chain-referral-sampling of a hidden population begins with a convenience sample of the initial subject. Respondent driven sampling techniques of 
snowball sampling are allowing the researcher to make asymptotically unbiased estimates from samples under some conditions (Jonhston \& Keith, 2010). Hence, snowball sampling and respondent driven sampling allow participants to make estimates about the social network connecting the hidden population.

The first sample selection criterion for both the interviewees and FGD participants in rural areas was the age of participants. The most important reason for this sample selection criterion was that folk media forms are associated with the language, history, and culture of the people. It suggests that elsewhere for daily communication purposes folk media forms remains as useful tools to express the language, culture, and history of the people in a given geographical setting. Thus, understanding folk media types and forms requires recalling the past and relating it to the present. To elaborate on these details, knowledgeable community elders play a key role. Community elders are highly trusted and esteemed by their respective members. Besides, they are responsible to transfer the language, history, and culture of the people as they have a better understanding of the nature, and history of folk media forms. Due to this, people from the ages 50 years and above were selected to provide details about the nature and history of the folk media types and forms, the role of folk media forms in the society, their folk media preferences, and their understanding of the potential of folk media forms for environmental communication.

Folk media forms are widely practice in various segments of the rural population in different contexts. Even so, this does not necessarily mean that all community members equally understand the nature, history, and importance of each of the folk media forms. This denotes that rural people have varying degrees of understanding the history of folk media forms and their significance to rural people, both of which may determine individual folk media preferences. Therefore, the main reason to focus on the ages 50 years and above is because these age groups are belief to have a wealth of experience attained through learning from their ancestors, through repeated use, or due to their involvement in various folk media performances. Additionally, both in individual interviews and focus group discussions, participants under the ages of 50 years are also select to respond to different questions related to the practices of folk media forms in rural areas, their folk media preferences, folk media uses across gender groups and their insights about the potential of folk media forms for environmental communication.

Therefore, to fully understand folk media types and forms in rural areas in Guna, both the elders and the young are equally relevant as each of them have complementing details about folk media forms and their potential for environmental communication.

The second sample selection criterion to select interviewees and FGD participants of this study uses related to gender. The reason to use this sample selection criterion is to examine folk media uses across gender groups in the community. In rural areas, folk media forms are widely practices among people.

The third sample selection criterion is based on the active involvement of individuals in environmental communication in the kebele level. Interview participants from the concerned government bodies were selected. The total sample size in this study was comprised of 16 FGDs and 45 individual interviews. Out of the 45 interviewees, 5 of them were from the regional and district officers as well as development agents, but the remaining 40 interviewees are community members from four kebeles. All the FGDs are undertaken with the community members in all kebeles. Each FGD group involved 5 to 8 people as this number was manageable to maintain active interaction of FGD discussants, as mentioned above. This sample size was justified as an 
ethnographic sample size was determined based on "what will be useful, what will have credibility and what can be do with available time and resources" (Patton, 2002).

\subsection{Data collection tools specification}

1. Preparation of comprising 16 unstructured interview questions that designed to assess the types of folk media, and the community level of knowledge for environmental communication of the target community of the Guna is the first. These interview questions also included questions concerning the folk group's performances. However, the questions were varied and flexible depending on age and gender variations. In total, 40 community members were participating in this interview.

2. Preparation of another 14 in-depth interview questions aimed at the environmental communication in the conservation of Guna Mountain. Questions relating to EC were presented in the same spirit as those included in the questions aimed at the target environmental experts, and communication strategists. In this in-depth interview, five environmental experts (4 kebele and 1 zone) participated.

3. Preparation of 12 FGD questions was also the third method to assess the types of folk media which they use for environmental communication at different levels for different themes. The FGD questions were varied depending on the types of FGD groups, but the central idea was similar that talks about the use of folk media.

4. In addition to these, 21 participant observation checklist questions prepared to assess the real folk media, which they used for environmental communication.

5. Finally, text analysis tools in question form were prepared to interpret and analyze the written texts.

\subsection{Data analysis procedure}

The data collected through observation, interview, FGD, and document review produces three kinds of data: quotations, descriptions, and excerpts of documents, resulting in one product: narrative description. This narrative often includes charts, diagrams and additional artifacts that help to tell the story (Hammersley, 1990)

To analyze interview data, all data that were collected coded accordingly. Tabulated responses were carefully analysis in a way that sensible meanings emerge out of the organized data. Moreover, observation-based field notes were coded into themes based on the matrix of observation to identify and formulate all ideas, or issues they suggest (Emerson, Fretz, \& Shaw, 2011). For document analysis, the researchers followed the procedures outlined of (Startt \& Sloan, 2003). They skeleton the following five types of controls that help interpretation of documents: evidence, context, the status of historical writing on the topic, generalization, and self-discipline.

\subsection{Results and Discussions}

Based on the objective of the study, this survey tried to investigate the types of folk media in the Guna community, interpreted the implications of folk media usage for current ecological 
preservation, and assigned selective folk media for advocacy in developmental activities to conserve Mount Guna.

In this research, 128 FGD respondents in 16 groups participated in four kebeles. The majority of the respondents were males, who are in age 20-70, and also most of the respondents were illiterate and married, that leads their life by agriculture. In addition to this, forty folk artists and five environmental experts selected for an in-depth interview. In Guna, aged males are popular in folk media. They performed the folk media for their socio-economic interaction. The inhabitant's livelihood is characterized by subsistence agriculture, which includes crops, farming, and animal husbandry. So, the ecosystem elements of Mount Guna are critically important for the local community subsistence; provide fodder, water, construction material, firewood, etc. The community habituated in and around the conservation area. However, the ecosystems become degraded and destroyed the form of grazing and plow. The ecology degraded in extensively use the natural resources unwisely exploited the natural resources and lack of awareness in environmentalism. To avoid this, EC is the best solution.

Guna Community is rich in terms of several traditional folk media. They express their feelings, opinions, and communicate by using folk media. Their ways of living style, cultural games and practice, harvest methods, marriage arrangement, and wedding ceremony, heroic rituals, patriotism songs, beliefs, children's anecdote rounding the fire and fairy-tale, myths, the wax and gold talk among elders are the very few to be mentioned. Guna community uses them to communicate in their environments for environmental messages. All their lives are bounded by this medium of communication.

In Guna, the community has a similar culture, religion, language, and working habits, so it is simple to address the message simply and can create awareness about the environment. Now a time being, modern media coverage is none in this area; they also haven't any energy to run any electronic medium. The community hasn't any media access to grasp environmental messages, so it is tough to address it, development agendas, and projects. Though, folk forms of communication can help massively address the environmental and related messages. Folk media can play a vital role inn ecological preservation in form of EC. They facilitate environmental issues to communicating with the rural people in rural areas which incorporating latest messages. They are smart enough to transmitting environmental messages to the mass illiterates and literates. The language, dialect, ways of expression is simple and usual.

Folk media are not only effective for ecology preservation; it should be an integral part of any communication program for rural development. The communities worked communal activities on their farm lands in the winter season every year. The women also have coffee ceremony programs to discuss health issues. They use folk media during this development program. The question here is that knows and understands the community culture, value, religion, and custom are the basics. That means they have the privilege to use folk media for ecology preservation. Guna community is rich in traditional folk media that are intimate with their culture, believes, value, and religion. Guna community has secular folk music, songs, and dances, oral folk literature in forms of campfire stories, traditional motifs, designs and symbols, out-door and indoor traditional fairs and festivals, and folk poems. They used these folk media to relax, educate, 
preserve history, and beautify the idea, express ideas in concise, test, insult, traditional debate, win, share information, to discuss in the issues.

Folk media is an excellent tool to enhance communication and to promote dialogue at the grassroots level of any society. They have the power to educate, to alert, to persuade, and to help the community to solve environmental problems. It is one part of pragmatic EC. It is personal in the form of message development and performance, and they have an acceptance in the people's minds. It uses local language, dialects, and local talents though it is simple in the form of message development and immediate rapport and has prompt feedback. It is easy to interpret and has entertainment elements. Thus, they have an advantage for development, empowerment, and entertainment.

The majority of the community has high perceptions of the usage of folk media in their areas. The inclusiveness, proximity, simplicity, and indigenous nature of the media are the best quality to recommend for development activities. It is usually used at the small cluster to communicate with the society that to use in the form of face-to-face communication procedures. Heroic recitals/patriotism songs, harvest home songs have the power to reach easily at any level and change the mind of the people. The flexibility nature of the songs can incorporate different development themes to inspire and shape the community attitude.

Besides this, the community is active using folk media. The highlanders have their secular folk music, songs, and dances inform of heroic recitals, patriotism songs, harvest home songs, songs of compliant, woe and sadness, whisper, sound signals, secular Gondergna music, and dances. In addition to these, the oral folk literature forms; fairy tales, myths, puzzles, idioms, silanitiya, jocks, bela libeliha talks, sayings, and proverbs are the community folk media which categorized under the campfire stories. The community uses them at field and home; however, the oral folk literature used to beautify their evenings. They used to relax, educate, preserve history, beautify the idea, express ideas in short, test, insult, traditional debate, win, share information, to discuss the issues.

Also traditional motifs, designs, and symbols are the outcomes of mythology, religious beliefs, traditions, and philosophy of the community. The community commonly uses religious traditional motifs like cross, tattoo, symbols, and holy water in the bottle. The traditional motifs, designs and symbols are significant in the environmental communication that relates to the culture, norm, and values of the community. The community beliefs that the motifs, designs, and symbols protect themselves with evil spirits, beautify themselves, protect with the evil eyes, protect their crops with pets, and protect the home, family, and evil spirits.

The community celebrated their religious-based traditional fairs and festivals in their locality. They have many fairs and festivals, but they can be categorized depending on the number of participants and pace of celebrated, outdoor, and indoor festivals.

The outdoor festivals are Epiphany, Findings of the true cross, celebrations (Nigis), and the indoors are, New-year, Christmas, Eastern, tishit (phantom/demon), wedding, death, and faith association (Mahiber). They are religious, cultural, and social, and they celebrated to pride the Ark of the Covenant, blessed, honor true Jesus Crist cross, thanks to St. Elaine, blessing, and celebrating socio-cultural issues. 
The other is folk poems; these are a blessing, praise, curse, social commentary, historical record, and cherishing patriarchy. However, all folk poems have their functions in folk songs, music, dances, stories, so we don't see deeply here on this part.

Folk media use for sustain ecology preservation in form of EC that is an exercise in the form of sharing environmental information, deep insights, and opinions on environmental issues, trends, conditions, and solutions using any means of communications to educate the people about the environment to conserve Guna Mount. Fit address environmental messages to the community easily to creating awareness. The messages can shape the attitudes of the community to conserve the biodiversity and protected areas.

The main focus in environmental communication is to inspire and develop positive behavior on individuals, communities, corporate and industrial bodies, and others to help conserve the environment and achieve sustainable development in any community level. In this context, the government and policy makers didn't invest in teaching the community about the environmentalism. Folk media will also play significant role to entertain and educate the community for the upright behavioral effects.

They have the power to educate, to alert, to persuade, and to help the community to solve environmental problems. Folk media is the best medium to address the environmental message effectively to the communities that are literate or illiterate. It has a capability and preferably to incorporate and transfer relevant messages to the community. It teaches them informs of EC to do/conserve the mount for as moral obligation because the environment is everything for the earth; ecosystem, humanity, biodiversity. So, as human beings that we live on the earth, we have to preserve and conserve the environment and give a safe environment for the future generation.

In Guna, the community has a similar culture, religion, language, and working habits, so it is simple to address the message easily and can create awareness simply on the people. Now a time being, modern media coverage is none in this area; they also haven't any energy to run any electronic medium. The community hasn't any media access to grasp environmental messages, so it is hard to address environmental messages, development agendas, and projects. Though, folk forms of communication can help massively address the environmental messages.

To select and assign folk media for rural development is difficult; it requires an extended assessment of the use of folk media. However, it is simple to recommend them depending on the data that collected in the field observation.

- Folk poems and songs, and singing styles for Entertaining, patriotism activities, showing personal skills (computation), motivate the people, educating, praising, criticism etc.

- Campfire Storytelling for Narrate the community stories, entertainment, transmitted community history to the next generation, test the insight view of the community (wisdom), discuss social and political issues, disseminate information, beautify development messages, Edutainment, develop thinking capacity.

- Secular, traditional folk-music and dances for Entertaining, history preservation, socialization, patriotism, nationalism building, 
- Fairs and festivals (social, ritual and ceremonial gathering) for Entertaining, trade, socialization, economy empowerments, cultural development

- Rites and rituals for Health therapy, environmental preservation, socialization, development activities

- Sound signals and speech surrogates for Emergency, code communication, alert

- Ritual symbols, traditional designs and miscellaneous motifs for Religious and cultural therapy, respect and represent the community religion, culture, norm, and tradition, develop and preserve the indigenous wisdom of the community

\subsection{Conclusions}

Guna community is rich in folk media which serve for EC. Folk media are efficacious for ecology preservation and developmental activities, but they didn't exploit intensely and used for developmental activities. The community has secular folk music, songs, and dances, oral folk literature in forms of campfire stories, traditional motifs, designs and symbols, out-door, and indoor traditional fairs and festivals, and folk poems. They used these folk media to relax, educate, preserve history, beautify the idea, express ideas in short, test, insult, traditional debate, win, share information, to discuss on the issues. Besides these, they have great significance for the socio-cultural interactions. Folk media have the power to share environmental messages that educate the community. The medium is smart to create awareness about environmental issues. Using these media for EC is the best means to preserve Mount Guna. Thus, policymakers, developmental agents, and different governmental and NOGs organizations have to use folk media to address environmental messages.

\subsection{Recommendations}

Based on the conclusion of this study, the researchers tried to forward the following recommendations.

- The development experts and policymakers have to use folk media to shape the attitudes of the community.

- Folk media have the capacity and flexibility to carry preferable and seasonal information in development projects, so we have to use it as an alternative means of message medium.

- Advocators of development have to use them because they have acceptability in the community, and they have the power to change the mind of the people.

- Researchers have to see in-depth each type of folk media because this is only an assessment study. Each medium have their own signature to dig indigenous knowledge, personal attitude, society's culture, values, norms, religious and socio-economic status, etc.

- Folk media should be an integral part for any motivational program of development programs in the Guna Community in the form of edutainment and infotainment.

\section{Acknowledgment}

We would like to thank in the heart our respondents, the Guna Community, and the people that contribute to the accomplishment of this work. We want to give special thanks to Mr. Desalegne Yeshambel and Mr. Hagos Kahasay for the initial of this work. 


\section{Bibliography}

Ansu K. "Theory and Application. Accra, Ghana: School of Communication Studies, University of Ghana, Legon." Perspectives in Indigenous Communication in Africa (1998): vol 1 p3.

Ashenafi, Kebede. "The Music of Ethiopia: Its Development and Cultural Setting". Phd diss. ProQuest Dissertations and Theses. Proquest Dissertations. 1971.

Assefa A. "Analysis Of Heroic Recitals (FUKKERA) of North Gondar With Special Focus on Tegede and Armaciho Woredas." AAU Institutional Repository (2009).

Bandura A. Social Learning Theory. New York: General Learning Press, 1977.

Bandura. Social Foundations of Thought and Action: A Social Cognitive Theory. Englewood Cliffs: NJ: Prentice-Hall, 1986.

Barbara Yount. Folk media and mass media in population communication. France, 1982.

Barbara, Yount. Media Development Specialist. Honolulu Hawaii: East-West Centre, , n.d.

Basappa, Bangari. "ROLE OF TRADITIONAL FOLK MEDIA IN RURAL DEVELOPMENT." www.reviewofresearch.net (2012): Vol.1, Issue. 11.

Bhagwati, Shukla Charan. "Environmental Education in Asia and the Pacific." Pioneer Institute of Professional Studies 1006 2016: 1-2.

Bryman. Social Research Methods (2nd ed.). Oxford: Oxford University, 2004.

-. Social Research Methods (2nd ed.). Oxford: Oxford University, 2004.

Bryman, A. Social Research Methods (2nd ed.). Oxford: Oxford University, 2004.

Center, Guna Tana Field Integrated and Development. Meeting with Guna Community Representatives: Guas'sa Council . Debre Tabor: Debre Tabor University, Apri 21-22/2016.

Cialdini and Trost. Social influence: social norms, conformity, and compliance. Boston: McGraw-Hill, 1998.

Denzin, N. K. The research act: A theoretical introduction to sociological methods (2nd ed). New York: McGraw-Hill, 1978.

Deva, Indra. "Folk Culture and Peasant Society in India." Rawat Publications (2013): 1-2.

Emerson R, Fretz R and Shaw L. Writing ethnographic field notes. Chicago: The University of Chicago Press, 2011.

Fetterman D. Ethnography: Step by step (3rd ed.). Los Angeles: Sage, 2010.

Fetterman D. Ethnography: Step by step (3rd ed.). Los Angeles: Sage, 2010.

Flick U. An Introduction to Qualitative Research (2nd ed.). London: Sage, 2002.

Flick U. Managing Quality in Qualitative Research: Qualitative Research Kit. London: Sage, 2008. 
Flick, U. An Introduction to Qualitative Research (2nd ed.). . London: Sage, 2002.

Flor Alexander. Principles, Approaches and Strategies of Communication Applied to Environmental Management. Diliman, Quezon : Up Open Univerisity, 2004.

Flor, Alexande. Eniviromental Communication: Principles, Approaches and strategies of Communication Applied to Eniviromental Management. Diliman Quezon: University of the Philippines-Open University, 2004.

Getie Gelaye. "Peasant Poetics and State Discourse in Ethiopia: Amharic Oral Poetry as a Response to the 1996-97 Land Redistribution Policy." Northeast African Studies, Volume 6, Number 1-2 (1999).

Gilpin. Dictionary of Environment and Sustanable Development. Chichester, N.Y.: J. Wiley, 1996.

Gilpin, A. Dictionary of Environment and Sustainable Development. Chichester, N.Y.: J. Wiley, 1996.

Gobo, G. Doing Ethnography. London: Sage, 2008.

Hammersley. Reading Ethnographic Research: A critical Guide. Londen: Longman, 1990.

Haradhan Mohajan. "Qualitative Research Methodology in Social Sciences and Related Subjects." Journal of Economic Development, Environment and People, Vol-7, Issue 01, 2018, pp. 23-48 (2018).

Harris, Usha Sundar. Participatory Media in Environmental Communication: Engaging Communities in the Periphery. London: Routledge, 2018.

Heckathorn, DD. "Snowball Versus Respondent-Driven Sampling." Sociol Methodol (2015): 41(1): 352366.

Hubley. Communicating Health: An Action Guide to Health Education and Health Promotion. London, England: Macmillan Press Ltd, 1993.

Hubley, J. Communicating Health: An Action Guide to Health Education and Health Promotion. London, England: Macmillan Press Ltd, 1993.

"Indian People's Theater Association." Pre Independance India 1943.

Jarreau Brown, Altinay Zeynep and Reynolds Amy. "Best Practices in Environmental Communication: A Case Study of Louisiana's Coastal Crisis, Environmental Communication." Australian National University (2015).

Jinadasa Manoj. "Community Development Programmes and Folk-Media: A Communication Model for Sri Lankan Rural Society." Global Media Journal (2011).

Johnson Orna and Harris Marvin. Cultural Anthropology, (5th ed.). Allyn and Bacon: Needham Heights, MA, 2000.

Jonhston LG. and Keith S. "Smpling Hard To reach Population with Resspondent-Driven sampling." Methodological Innovations Online (2010): 5(2): 38-48. 
Juvvigunta, Janardhan. Folk Media In India. 2017.

Kahssay, Hagos Nigussie. "Folk media forms and their potential for food security communication in eastern Tigray,Ethiopia." University of Queensland (2017).

Knoot, Tricia. "understanding and promoting human care for nature. ." Landscape Ecology (2011): 26.10.1007/s10980-010-9545-3.

Kodavath, Yathish.L. " Folk Media as a Mode of Communication in the Development of Rural Areas." (2015): Volume-4, Issue- ISSN No 2277 - 8160.

Kruger R and Casey M. Focus Groups: A Practical Guide for Applied research (4th ed.). Los Angeles: Sage, 2009.

Kumar, Shailendra. Role of folk media in Nation Building. Lucknow: University of Lucknow, 2012.

Kvale, S. Doing Interviews. Thousand Oaks: CA:Sage, 2007.

Manfred, Oepen. Environmental Communication for Sustanable Development. Frankfert: Environmental Communication Resource ceneter, 2000.

Mbella Josephhine. Reasons for using folk media. n.d.

Mohammad Noor. "The Role of Media on the Environmental Communication for Protecting the Society." A Sustainable Approach. Pakistan Journal of Social Sciences (2013): 10: 126-134.

Morse, J. Strategies of intra project sampling. In Munhall, P. L. (Ed.), Nursing Research: A qualitative perspective (4th ed.). Sudbury, MA: Jones \& Bartlett. New Delhi, 2006.

Murchison, J. Ethnographic essentials: Designing, conducting and presenting your research. Hoboken: John Wiley \& Sons Inc., 2010.

Narayana), N.Usha Rani (Usharani. "Role of Folk Media in Rural Development Third Concept, New Delhi." (1994): Vol.8, No.94.

Obijiofor L. New technologies in developing societies: from theory to practice. NY: Palgrave Macmillan, 2015.

OECD. Environmental Communication - Applying Communication Tools towards Sustainable Development. 1999.

Oepen Manfred. Eniviromental communication for sustainable development. Frankfurt, 2000.

Pamr and Shyam. Traditional Folk Media in India. New Delhi: Geka Books, 1975.

Paris Okely. Anthropological Practice: Fieldwork and the Ethnographic Method. Oxford: Berg, 2012.

Patton, Q. M. Qualitative Research and Evaluation Methods (3rd ed.). Newbury Park: CA: Sage, 2002.

Paul Stern Stern and Dietz Thomas. Public Participation in Environmental Assessment and Decision. Wahington DC: The National Academies Press, 2008. 
Phil Long, Lyck Lise and Xenius grige. Tourism, Festivals and Cultural Events in Times of Crisis. Denmark: Frederiksberg bogtrykkeri, 2012.

Prasad, Dr. Neeru. "Folk Media: an active media for communication campaigns in digital era. In Commentary-1." Global Media Journal-Indian (2013): Vol.4/No.2, www.caluniv.ac.in/Global media journal/Commentar.

Ranganath, H.K. Folk Media and Communication. Mysore: Chintam Prakashana, 1980.

Raymond, Williams. Keywords : a vocabulary of culture and society. United State: Oxford University Press, 1983.

Ritchie J. and Lewis J. Qualitative Research Practice: A Guide for Social Science Students and Researchers. London: Sage, 2003.

Ritu Asha. "Know Your Folks: Traditional Folk Media In India." YKA 2010.

Rogers EM. Diffusion of Innovations. New York: Free Press, 1995.

Román Nunez and Cuesta Moreno. "Revista Latina de Comunicación Social." (2016): Issue 71, p15-39.

Sarantakos S. Social Research (4th ed.). New York: Palgrave Macmillan, 2013.

Sharma Anshul and Singh Namrata. "ROLE OF FOLK MEDIA IN RURAL DEVELOPMENT." International Journal of Education and Science Research (2015): ISSN 2348-6457 Volume-2, Issue-2.

-. "ROLE OF FOLK MEDIA IN RURAL DEVELOPMENT." International Journal of Education and Science Research ISSN 2348-6457 Volume-2, Issue-2 (2015).

-. "ROLE OF FOLK MEDIA IN RURAL DEVELOPMENT." International Journal of Education and Science Research ISSN 2348-6457 Volume-2, Issue-2 (2015).

Sharma, Seema and Gupta. Fairs and festivals of India. Delhi: Puatake Mahal, 2006.

Shukla Charan. ENVIRONMENTAL COMMUNICATION. Indore: Institute of Professional Studies, 2016.

Startt J. and Sloan Wm. Historical Methods in Mass Communication (Revised ed.). USA: Vision Press, 2003.

Valbuena Victor. "Using Folk Media in Development Programmes." Media Asia (1988).

Vijaya N. The Role of Traditwnal Folk Media in Rural Areas. Delhi: Gian Publishing House, 1975.

Wang, G. and Dissanayake,W. Culture, Development and Change: Some Explorative Observations. In Continuity and Change in Communication Systems. From Sreekumar, C.S. Folk Arts as Mass Communication Media. www.sikhspectrum.com/112007/folkarts.htm, 1984.

Whitehead, Tony L. Basic Classical Ethnographic Research Methods. Maryland: College Park, 2005.

Yount Barbara. The use of folk Media in Developing Countries for motivational purpose. 1976.

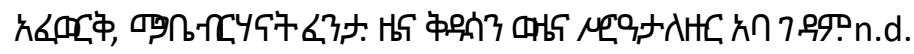


Ng'ombe JL. (2000). "The communication model and folk media in Development". In Van Der Stichele P (Artrcle editor) folk and traditional media for rural development: A workshop field in malawi Liiongwe 23 August-3 September 1999. Sd: knowledge: communication for development. Posted January 2000 p. 5

Essays, UK. (November 2018). Traditional and Folk Media in Development Communication Role, communication-6388.php?vref=1) 2018

The Drum Beat - Issue 393 - Let's Use Folk Arts and Traditional Media for Development, May 7 2007 Working Party on Development Cooperation and Environment (WPDCE). (1999). Environmental communication: Applying communication tools towards sustainable development [Working Paper]. Paris Cedex: Review of Research [2249-894X] yr:2012 vol:1 iss:11 2012

Anshul Sharma, Namrata Singh. ROLE OF FOLK MEDIA IN RURAL DEVELOPMENT, International Journal of Education and Science Research ISSN 2348-6457 Volume-2, Issue-2 (2015).

Webs

https://www.ncbi.nlm.nih.gov/pmc/articles/PMC1446824/

http://www.kkhsou.in/main/masscom/rural_agriculture.html

https://www.caluniv.ac.in/global-mdia-

journal/Winter\%20lssue\%20December\%20\%202011\%20Articles/AR-4\%20Jinadasa.pdf

www.caluniv.ac.in/Global media journal/commentary dec. 2013/Commentary1NeeruPrasad.pdf : Deva, Indra. Folk Culture and Peasant Society in India, p1-2, Rawat Publications. As referred by Prasad, Neeru.(2013) Folk Media: an active media for communication campaigns in digital era. In Commentary-1,Global media journal - Indian edition. ISSN 2249- 5835, winter issue/December 2013/Vol. 4/No.2 p.2.

http://bieap.gov.in/Pdf/FGMPaperIIYR2.pdf : FRANCES JULIA RIEMER: Lapan c11.tex V1 09/02/2008 5:10pm Page 203

Meeting held on Apr 21-22/2016 in Debre Tabor University with Guna Community Representatives.

https://static1.squarespace.com/static/55386ad8e4b002ebf3fcf717/t/58e5bc172e69cf70e7b57 981/1491450907205/JarreauAltinayReynolds2015+\%281\%29.pdf . (n.d.).

https://static1.squarespace.com/static/55386ad8e4b002ebf3fcf717/t/58e5bc172e69cf70e7b57 981/1491450907205/JarreauAltinayReynolds2015+\%281\%29.pdf . n.d. 